\title{
Vietnamese and Chinese Culture and Motives for Being an Entrepreneur Among Immigrants From Vietnam and China Settled in Poland
}

\begin{abstract}
Agnieszka Brzozowska*
The text presents the results of a qualitative study conducted on a group of immigrant entrepreneurs from Vietnam and China who run their businesses in Poland. The team of researchers conducted a total of 24 in-depth interviews. Interviews were recorded, transcribed and analyzed against assumed research areas. For the needs of the text, the analysis will present the motives for starting own business by the selected group of immigrants in Poland and the link with their national culture. As it turns out, the motives will be very different depending on the ethnic group. It could be assumed that the culture of origin will be of great importance in the perception of entrepreneurship and in shaping the will to be an entrepreneur. Support from the ethnic community for running a company means that many people decide to take this risk, even if they did not necessarily have such plans before. Through the prism of analyzing entrepreneurial motives, we can observe different patterns of coping in the host country. The limitation of the study is the sample of respondents, which may not show the most common motives due to the targeted selection.
\end{abstract}

Keywords: immigrant entrepreneurship, the Far East, motives for starting a business.

Nadesłany: 02.08.18 | Zaakceptowany do druku: 11.10.18

\author{
Wietnamska i chińska kultura \\ oraz motywy przedsiębiorcze wśród imigrantów \\ z Wietnamu i Chin osiadtych w Polsce
}

Tekst przedstawia wyniki badania prowadzonego metoda jakościowa na grupie imigrantów przedsiębiorców pochodzacych z kraju Dalekiego Wschodu, którzy prowadza swoje firmy w Polsce. Zespót badaczy przeprowadzit z imigrantami tacznie 24 wywiady pogtębione na terenie catej Polski. Wywiady byty nagrane, poddane transkrypcji i przeanalizowane pod katem zatożonych obszarów badawczych. Na potrzeby tekstu przedstawiono analizę dotyczaca motywów zaktadania wtasnej dziatalności w grupie imigrantów i połaczeń ich z kultura. Jak się okazuje motywy $w$ zależności od grupy etnicznej będa bardzo różne. Można przypuszczać, że kultura pochodzenia będzie miata ogromne znaczenie w postrzeganiu przedsiębiorczości i ksztattowaniu chęci do bycia przedsiębiorca. Wsparcie wśród spoteczności etnicznej w kierunku prowadzenia firmy sprawia, że dużo osób decyduje się na ten krok, choć wcześniej niekoniecznie mieli

\footnotetext{
* Agnieszka Brzozowska - dr, Faculty of Management, University of Warsaw. https://orcid.org/0000-00029908-6427.

Correspondence address: Faculty of Management, University of Warsaw, ul. Szturmowa 1/3, 02-678 Warszawa; e-mail: abrzozowska@wz.uw.edu.pl.
} 
takie plany. Przez pryzmat analizy motywów przedsiębiorczych możemy zaobserwować różne wzory radzenia sobie $w$ kraju przyjmujacym. Ograniczeniem badania jest próba badanych, która z powodu doboru celowego może nie pokazywać przewag wśród najczęstszych motywów.

Słowa kluczowe: przedsiębiorczość imigrantów, Daleki Wschód, motywy rozpoczęcia działalności biznesowej.

Submitted: 02.08 .18 | Accepted: 11.10 .18

JEL: Z19, Z13, O15

\section{Introduction}

Many studies have investigated the phenomenon of immigrant entrepreneurship worldwide (Kloosterman, 2010; Portes \& Jesnen, 1986; Sanders \& Nee, 1996; Vinogradov, 2011). In 2012, for the first time in the history of the GEM (Global Entrepreneurship Monitor) report, one of the most comprehensive and well-known studies on entrepreneurship, it covered immigrant entrepreneurship. Entrepreneurial immigration has a substantial impact on the economy of the host country. As Zhou (2004) notes, immigrant entrepreneurship can affect the market in the host country in three ways: create employment opportunities for people who are disregarded by the main labor markets, reduce competition with native employees and, by developing entrepreneurial models, provide immigrants with the opportunity to increase their earnings.

In Poland, the topic of immigrants still requires new research efforts, not only with regard to foreigners in the labor market (Grabowska-Lusińska \& Żylicz, 2008; Kubiciel-Lodzińska, 2017) but also concerning immigrant entrepreneurship (Brzozowski, 2008; Glinka \& Brzozowska, 2015). In Poland, the subject of migrant entrepreneurship is relatively new, because Poland has not been a target country for migrants so far and till 1989 we were a communist country so there was no entrepreneurship. However, now the number of immigrants in Poland is increasing. Our country has turned from a transit country to a destination country for settlement or a host country (Castles \& Miller, 2011) so there is a need to observe phenomena occurring in the society, considering the migration aspect

In Poland, there are not many immigrants because they represent less than 1 percent of the entire population. The biggest group of immigrants comes from neighboring countries like: Belarus or Ukraine. However, the second biggest immigrant community are people of Vietnamese and Chinese origin. There is also an increasing number of Indians. Koreans are quite a visible group.

The reason for the research is that the phenomenon of migrations attracts growing attention, and is analyzed from many different perspectives. The economic side of migrations is considered to be crucial for understanding immigrant groups, their motives and actions. I will understand an immigrant as a person who has foreign nationality. This means that immigrants will also be people already born in our country, the second generation of immigrants (OECD, 2005, p. 116). I will understand an immigrant entrepreneur as the owner of a business who has a non-native origin, is involved in economic activities and is profit-oriented in the market (Butler \& Greene, 1997). The aim of the article is to provide some insight into entrepreneurial activities of immigrants from Vietnam and China who established their companies in Poland. In the article, I discuss the main motives for starting new ventures and sources of opportunities for migrant entrepreneurs from the mentioned countries in Poland. Findings from this study are based on the research material from a qualitative study conducted in 2018 in Poland. The study is a part of a bigger project "Entrepreneurship of Immigrants from the Far East in Poland" financed by the National Science Centre.

\section{Motives for Establishing \\ Enterprises}

The issue of immigrant entrepreneurship is multidimensional and complex. Immigrants, especially the first generation, 
establish their businesses between two cultures, the country of origin and the host country. Running a business in a foreign country is a very difficult task and requires many different competencies, among others knowledge about business and culture of the host country, habits of the host country, knowledge of customer preferences and business environment, a network in a completely new place, and quick adaptation. It is interesting, therefore, what influenced the decision to become an entrepreneur.

There are many approaches explaining the preferences of immigrants to choose an entrepreneurial path or describing the nature of their entrepreneurial activities. Depending on the adopted research perspective, different aspects of the entrepreneurial phenomenon of immigrants are considered.

The simplest division of theories on motives for immigrant entrepreneurship is into two groups: pull versus push factors (Bates, 1997; Fairlie, 1996). Pull factors are related to positive aspects of self-employment and being entrepreneurs by choice (Fairlie \& Meyer, 1996).

On the basis of sociology, there are two main groups of concepts related to the reasons for setting up businesses by immigrants: the cultural theory and the disadvantage theory (Volery, 2007). The disadvantage theory indicates that immigrants set up their own businesses because it is practically the only way in which they can earn a living in a new country; it is, therefore, a form of necessity (forced) entrepreneurship (Chrysostome, 2010). However, as some research shows, entrepreneurship can also be a more profitable way of building a professional career in a host country than finding a job on a local labor market (Portes $\&$ Rumbaut, 2006). Moreover, Fairlie and Meyer (1996), on the basis of research in the USA, have indicated that an ethnic group's self-employment rate is positively associated with the difference between self-employment and wage (salary) for that group. Research presenting that freedom, autonomy and work flexibility are one of the biggest motivation among immigrant entrepreneurs is more visible in this field (Shinnar, 2007). For immigrants, being an entrepreneur is the chance to get higher income (Bearse, 1984; Sullivan, 1981).

Cultural theories focus on specific, culture-rooted characteristics of immigrants that make them more likely to create new ventures (Light \& Rosenstein, 1995; Masurel, Nijkamp, \& Vindigni, 2004). These concepts also discuss cultural origins of choice of business and industry type (Leung, 2002). The cultural perspective seems to be very interesting in terms of how origin can be conducive to entrepreneurship. Culture as postulated by Fukuyama (2001, p. 3132) affects economic activity, efficiency of institutions, building social networks as well as self-confidence of entire communities.

In literature, there are voices that the immigrant group is very important in decision-making about establishing a company. However, the effect of the group is unclear. In some studies, authors (Aldrich \& Waldinger, 1990; Razin \& Langlois, 1996; Mora \& Dávila, 2005) suggest that the size of the group negatively affects the decision to become an entrepreneur. If there are too many entrepreneurs, then people rather choose to seek salaried positions. On the other hand, other studies show that if there are many entrepreneurs in an ethnic group and the ethnic group is large, it makes it easier for immigrants to acquire capital, attract a large consumer base and seek greater profits from their entrepreneurial activities so more people decide to establish their companies (Yuengert, 1995; Evans, 1989; Guerra \& Patuelli, 2014).

Waldinger (1989) claims that immigrants establish their companies when they see opportunities to do that, when there are possibilities to be an entrepreneur in the host country.

\section{Culture and Entrepreneurship}

Hofstede (1980) suggests that national culture influences business. An entrepreneurial attitude and the way of making business arise from culture and shared values. Culture shapes entrepreneurial behaviors (Berger, 1991; Sobel et al., 2010). Schwartz (1992, p. 4) defines values as "concepts or beliefs that pertain to desirable end states or behaviors and transcend specific situations in guiding selection or evaluation of behavior and events and are ordered by relative importance". Values are a kind of program implemented by culture as a collective way of thinking and perception (Hofstede, 2001; Kilby, 1993).

For the Vietnamese ethnic group of entrepreneurs, Morris and Schindebutte 
(2005) noticed values which are manifested in business practices such as: protection of independence, search for parity/respect, risk avoidance and helping others. For the Chinese ethnic group of entrepreneurs, values manifested in business practice are: hard work, detail orientation, long-term orientation, excellence, obligation towards the group/social integration.

In the paper, I focus on the link between culture and motives for establishing company by immigrants. The main aim of the paper is to analyze if there are differences between two immigrant groups in terms of motives for conducting business. There is still a need to analyze how immigrant groups from different countries behave in the host country.

\subsection{National Culture}

Analyzing the cultural dimensions specified by Hofstede, we could observed that in the case of the Chinese there is high power distance, low individualism, high score of masculinity and long-term orientation, low uncertainty avoidance and indulgence. It means that Chinese people are influenced by formal authority and regulations. Also, they think that people should behave according to their positions in the social hierarchy and they should not have higher expectations. This is a highly collectivist culture. Family, group members are treated better than people from outside. There are preferences to employ people from the group. Chinese people are success-oriented and driven. Work and prestige are more important than the family. The Chinese are pragmatic and flexible. Pragmatism means that they evaluate situation depending on the context and time. There is no one truth. Saving money and investment are important in the context of the future. They are recognized as entrepreneurial and adaptable. However, they are rather more pessimistic and cynical than indulgent societies.

For Vietnamese people, we could observe high power distance, low individualism, low score of masculinity, with pragmatic orientation, low uncertainty avoidance and indulgence. In this society, hierarchy is very important. There should be a leader who indicates the direction of action. Like in the Chinese case, the Vietnamese are a collectivistic society. Family ties are crucial for many decisions. However, the Vietnamese are a feminine society so free time and flexibility are respected. Values desired at work are: equality among people, solidarity and quality. They are characterized by a low score of uncertainty avoidance, which means flexible schedules, unwillingness to over-regulate life and acceptance of events as they are. It is also a pragmatic culture with pessimism and cynicism.

\section{Method}

The described research is a part of the project "Entrepreneurship of Immigrants from the Far East in Poland" financed by the National Science Centre UMO-2016/21/B/HS4/00767. The main

Figure 1. Hofstede's country comparison

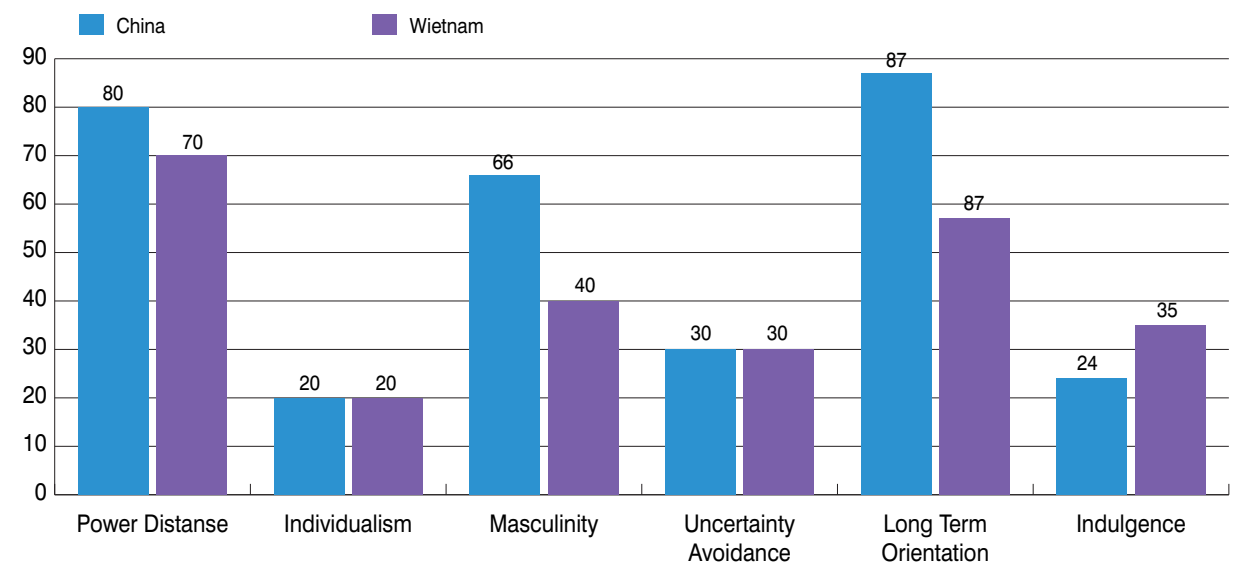

Source: https://www.hofstede-insights.com/country-comparison/china, vietnam/. 
objective of this project was to explore and understand entrepreneurial activities undertaken by immigrants from the Far East (China, Vietnam, South Korea, India, Philippines) in Poland. However, for the purpose of this study only two groups of immigrant entrepreneurs were analyzed: Vietnamese and Chinese. The research questions cover the following areas: the main motives for starting new ventures and sources of opportunities and differences between groups of Far East immigrants running their businesses in Poland.

In this project, two methods were combined: qualitative (stage I) and quantitative (stage II). Work was divided into two stages. The team of researchers, in 2018, did 65 open, anthropological interviews with first and second generation immigrant entrepreneurs from the Far East. A mix of snowball and diversity sampling methods were used to identify research subjects. Interviews were combined with direct observations. Interviews with Chinese entrepreneurs were conducted in Chinese, with Koreans in Polish or English, with Filipinos in English, with the Vietnamese in Polish and with Indians in Polish and English. The data collected were transcribed, coded and analyzed. For the purpose of this paper, the reasoning will be focused only on the main motives for starting new ventures and sources of opportunities for immigrants from Vietnam and China. 24 in-depth interviews were analyzed, 9 with Chinese and 15 with Vietnamese entrepreneurs.

\section{Motives of Immigrant Entrepreneurs}

In this section, the research material from the study will be introduced.

\subsection{Motives of Immigrant Entrepreneurs From China}

The Chinese community was the most hermetic group. People from this group were describing the process of observing entrepreneurial friends and family members as an inspiring experience. For the Chinese, every person in the community has a natural ability to run a business and they believe that the observation of others gives knowledge about business processes. That is why, for many of the Chinese, it is very natural to start a new venture as many of them do that. It is a part of their culture to coexist with entrepreneurship.

"From a very young age I observed the family and a friend who also have businesses, we were in contact, I got used to it." [C1].

There were also motives related to belonging to a certain regional group which is supposed to be characterized by entrepreneurial activity: "People from Qingtian prefer to be an entrepreneur." [C7]. It is worth mentioning that the Chinese were highlighting that people from some regions of China are exceptionally entrepreneurial and being an entrepreneur is their destiny.

At the same time, this person complained about the lack of opportunities to work in companies due to the reluctance to employ foreigners in Polish companies. "There was no chance, because Polish companies did not want to hire a foreigner." [C7]. Some of the Chinese were arguing that they had chosen that path to earn more money: "I want to earn more money." [C2].

Another Chinese respondent mentioned that he wanted to feel freedom and do a job connected with his skills and hobby. The best way to combine these two factors was to open his own company.

Chinese restaurant. I created the restaurant because I'm good at cooking, on the other hand, I think running a restaurant is freedom, and there's no need to listen to others. [C8]

Among members of this society, there were many sentences that showed how other countrymen had influenced their decision.

"I am married to a man who is from Zhejiang and influenced by his brave and entrepreneurial spirit, so I want to create my own business, to get the right of discourse in family." [C6]

During the interviews, the Chinese did not talk about their problems with finding a job. Rather, they presented the decision to become entrepreneurs as a voluntary decision, motivated by pull factors. However, it could be a cultural issue not to talk about problems to "save face". Nevertheless, there was still a lot of support and admiration for the people running their companies. It could be considered that a big influence on the decisions about the establishment of a company was exerted by the Chinese community with its acquiescence and even encouragement of such decisions. It also seems that the perception 
of entrepreneurship by compatriots has an irrelevant impact on the decision to establish a company. The communal approval of this career path means that the Chinese want to decide to become entrepreneurs.

\subsection{Motives of Immigrant Entrepreneurs From Vietnam}

Vietnamese people often mention that earning money and control of their life and money are a main motives for being an entrepreneur. "I know that everything what I earn is only for me" [V14]. They would like to decide about their life and manage their time and money.

"Having your own business requires more work. But I think that it (having company) always gives you flexibility" [V18].

They describe that they feel reluctant to have a boss. They prefer to decide for themselves and make money by themselves. They say that this belief is quite common among the Vietnamese.

"What I did not like? That I had a boss. I did not like it first of all." [V12]

However, despite their unwillingness to work for someone else and the desire to have this entrepreneurial freedom, they notice that this is practically the only way of promotion that is available for the Vietnamese if they were someone's employees in a Polish company.

"I think that even when they work full-time, they think about gaining experience and start their own business. Well, I think, the Vietnamese, I do not know, maybe they do not like being such a pawn, they do not feel good about it. Especially when they work for Poles, they do not feel comfortable when a Pole gives a command that they know is not good. Besides, most Vietnamese have a good education, and it is difficult for them to work for someone in a low position, because it is difficult for them to be promoted at work as they are not Poles ...”[R3]

Also in this case, like in other studied immigrant groups, there were people who were pushed by the market to establish their own company as they could not find a job. Sometimes it was the society that did that. Some of the Vietnamese inherited a business from their parents, so it was a natural path to be entrepreneur. There were also statements proving that the company was supposed to be the way to realize yourself and your ideas.
"I wanted to create my own. Following a wave of cool ideas, new ideas for gastronomy, I wanted to open a teahouse. I wanted to do something new, with good quality, something completely different, cool, original" [V10]

The situation of Vietnamese people is specific because many of them were educated in Poland, so they know Polish well, at least its basics, and they have a long history of migration to Poland comparing to other communities. It means that the probability of finding a job is higher than for other ethnic groups. Probably that is why they could focus more than other immigrants on realizing their dreams. They do not have a strong feeling that they are forced to run their business, but their treat it more like their own decision.

\section{Conclusions}

In the Chinese and Vietnamese societies, there is a very strong belief that being an entrepreneur is something very positive and worth implementing in life. This career path seems very prestigious and deserving of social recognition. Many members of these communities think about being entrepreneur and when the occasion appears, they do not have to think twice about the decision. What is more, they receive emotional, and sometimes even material, support from their kinsmen who persuade them to establish a company. The Chinese and Vietnamese have a very strong attitude toward earning more money, they are very focused on this goal and they consider the entrepreneurial path as the best way to achieve it. For some reason, only the Vietnamese highlighted that they had some problems with finding a job and that is why they were forced to establish their company. The Vietnamese strongly emphasized that they needed to control their lives and money. For the Chinese, a strong entrepreneurial family tradition was described as a considerable influence. They emphasized their affiliation to specific communities very much.

One of primary implications of the described research is that minority entrepreneurs are not a homogenous group. We could notice that the problem of finding a job or a satisfying job appeared during conversations as a driving force for selfemployment. However, a lot of entrepreneurs said that the central motive for 
running a company was the possibility to realize themselves and their ideas for life, which they could not do if they worked fulltime as employees. Cultural factors and entrepreneurial spirit among members of these communities were more noticeable and more often mentioned than push factors. It is worth mentioning that immigrant groups with the longest history of migration to Poland, like the Vietnamese and Chinese, have more motives connected to selfrealization factors than push factors. However, as I emphasized before, immigrants from Asian countries do not talk about problems and failures and it is related to the Asian culture. Especially that Chinese entrepreneurs, in contrast to the Vietnamese, did not speak Polish so all interviews were conducted in Chinese. Despite this, they do not think about finding a job in Poland, they rather think about running a company and they justify it by the need for self-realization and the need for realizing their dreams.

Considering the cultural influences on motives, it could be noticed that decisions of people from both societies are dominated by pragmatism. The rationale behind the establishment of a company as the fact that other Chinese in Poland also conduct businesses could be part of the cultural dimension associated with power distance and the principle of behaving like the others. So if being an entrepreneur is a natural choice of career path, then others also think about that. The willingness to fulfill ambitions could indicate a high level of the masculine dimension. Among the Chinese, there were no answers connected to free time, proving that their private time is of exceptional value. Among the Vietnamese, collectivism could be observed in statements about fostering strong relationships and responsibility for members of the family and taking over family businesses. Many interlocutors were mentioning that they do not like rules and they prefer to control their lives. It is convergent with low preference for avoiding uncertainty. Among motives for running a company, there were a few that indicated the need to do something that gives a sense of security and comfort better than work for Poles. Being an entrepreneur is considered a solution for better life and earning more money.

It seems that the culture of origin matters in how we interpret our actions.
Cultural dimensions are in line with how people motivate their actions. In the statements, we could recognize the values that people follow in taking actions and how they interpret reality.

A limitation of this study is that the analyzed cultures are Asian cultures so their representatives do not talk about problems and failures like in the Western countries. It could be problematic to receive answers related to this topics. Another thing is that the number of interviews from each community is not very big and the sample could be not representative.

\section{Endnote}

1 Project "Entrepreneurship of Immigrants from the Far East in Poland" was financed by the National Science Centre UMO-2016/21/B/ HS4/00767.

\section{References}

Aldrich, H.E., \& Waldinger, R. (1990). Ethnicity and entrepreneurship. Annual Review of Sociology, 16, 111-135. http://doi.org/10.1146/annurev. so.16.080190.000551.

Bates, T. (1997). Race, self-employment \& upward mobility: An illusive American dream. Washington, D.C.: Woodrow Wilson Center Press. Baltimore: John Hopkins University Press.

Berger, B. (1991). The culture of modern entrepreneurship. In B. Berger (Ed.), The culture of entrepreneurship (pp. 13-32). San Francisco: ICS Press.

Brzozowska, A., \& Postuła, A. (2014). The cultural determinants of entrepreneurship. An example of the Vietnamese immigrants running their own business in Poland. Problemy Zarzadzania, 12/4(2), 117-138. http://doi.org/10.7172/1644-9584.49.7.

Brzozowski, J. (2017). Immigrant entrepreneurship and economic adaptation: A critical analysis. Entrepreneurial Business and Economics Review, 5(2), 159-176. https://doi.org/10.15678/ EBER.2017.050209.

Butler, J.S., \& Greene, P.G. (1997). Ethnic entrepreneurship: The continuous rebirth of American enterprise. In D.L. Sexton \& R.W. Smilor (Eds.), Entrepreneurship 2000 (pp. 267-289). Chicago, Ill.: Upstart Publishing Co.

Castles, S., \& Miller, M.J. (2011). Migracje we wspótczesnym świecie. Warszawa: Wydawnictwo Naukowe PWN.

Chrysostome, E. (2010). The success factors of necessity immigrant entrepreneurs: In search of a model Thunderbird International Business Review, 52(2), 137-152. https://doi.org/10.1002/tie.20320. 
Evans, M.D.R. (1989). Immigrant entrepreneurship: Effects of ethnic market size and isolated labor pool. American Sociological Review, 54(6), 950-962.

Fairlie, R.W. (1996). Ethnic and racial entrepreneurship: A study of historical and contemporary differences. New York: Garland Publishing.

Fairlie, R.W., \& Meyer, B.D. (2000). Trends in self-employment among white and black men during the twentieth century. The Journal of Human Resources, 35(4), 643-669.

Fukuyama, F. (2001). Social capital, civil society and development. Third World Quarterly, 22(1), 7-20.

Glinka, B., \& Brzozowska, A. (2015). Immigrant entrepreneurs: In search of identity. Entrepreneurial Business and Economics Review, 3(4), 51-76. http:/ doi.org/10.15678/EBER.2015.030304.

Grabowska-Lusińska, I., \& Żylicz, A. (2008) Czy Polska gospodarka potrzebuje cudzoziemców? Warszawa: Centre of Migration Research, University of Warsaw.

Guerra, G., \& Patuelli, R. (2014). The influence of role models on immigrant self-employment: A spatial analysis for Switzerland. International Journal of Manpower, 35(1/2), 187-215.

Hofstede, G. (1980). Culture's consequences: International differences in work-related values. Beverly Hills, CA: Sage.

Hofstede, G. (2001). Culture's consequences: Com paring values, behaviors, institutions, and organizations across nations. Newbury Park, CA: Sage Publishing.

Kloosterman, R.C. (2010). Matching opportunities with resources: a framework for analysing (migrant) entrepreneurship from a mixed embeddedness perspective. Entrepreneurship and Regional Development, 22(1), 25-45. https://doi. org/10.1080/08985620903220488.

Kilby, R.W. (1993). The study of human values. Lanham, MD: University Press of America.

Kubiciel-Lodzińska, S., \& Maj, J. (2017). The tendency of entrepreneurs to employ foreigners: Labour immigrants in the opinion of employers. Central and Eastern European Migration Review, 6(2), 176-191. http://doi.org/10.17467/ceemr.2017.22.

Light, I., \& Rosenstein, C. (1995). Race, ethnicity, and entrepreneurship in urban America. New York: Aldine De Gruyter.

Mora, M.T., \& Dávila, A. (2005). Ethnic group size, linguistic isolation, and immigrant entrepreneurship in the USA. Entrepreneurship and Regional Development, 17(5), 389-404. https://doi. org/10.1080/08985620500275612.

Morris, M., \& Schindebutte, M. (2005). Entrepreneurial values and the ethnic enterprise: an exami- nation of six subcultures. Journal of Small Business Management, 43(4), 453-479.

Masurel, E., Nijkamp, P., \& Vindigni, G. (2004) Breeding places for ethnic entrepreneurs: A comparative marketing approach. Entrepreneurship \& Regional Development, 16, 77-86. https://doi.org/10 $.1080 / 0898562042000205045$

Portes, A., \& Jensen, L. (1987). What's an ethnic enclave? The case for conceptual clarity. American Sociological Review, 52, 768-771.

Portes, A., \& Rumbaut, R.G. (2006). Immigrant America: A portrait. Berkley, CA: University of California Press.

Razin, E., \& Langlois, A. (1996). Metropolitan characteristics and entrepreneurship among immigrants and ethnic groups in Canada. International Migration Review, 30(3), 703-727. http://doi. org/10.2307/2547633.

Sanders, J.M., \& Nee, V. (1996). Immigrant self-employment: The family as social capital and the value of human capital.American Sociological Review, 61(2), 231-249. http://doi.org/10.2307/2096333.

Schwartz, S.H. (1992). Universals in the content and structure of values: Theoretical advances and empirical tests in 20 countries. In M.P. Zanna (Ed.), Advances in experimental social psychology (pp. 1-65). San Diego, CA: Academic Press.

Shinnar, R.S. (2007). A qualitative examination of Mexican immigrants' career development perceived barriers and motivators. Journal of Career Development, 33(4), 338-375. http://doi. org $/ 10.1177 / 0894845307300413$.

Sobel, R.S., \& Dutta, N. (2010). Does cultural diversity increase the rate of entrepreneurship? The Review of Austrian Economics, 23(3), 269-286.

Vinogradov, E. (2008). Immigrant entrepreneurship in Norway (Doctoral thesis). Bod $\varnothing$ Graduate School of Business.

Vinogradov, E. (2011). Ethical aspects of research on ethnic/immigrant entrepreneurship. Entrepreneurship Research Journal, 1(3). https://doi. org/10.2202/2157-5665.1017.

Volery, T. (2007). Ethnic entrepreneurship: A theoretical framework. In L.-P. Dana (Ed.), Handbook of research on ethnic minority entrepreneurship. A co-evolutionary view on resource management. (pp. 30-41). Cheltenham, UK, Northampton, MA USA: Edward Elgar.

Yuengert, A.M. (1995). Testing hypotheses of immigrant self-employment. Journal of Human Resources, 30(1), 194-204.

Zhou, M. (2004). Revisiting ethnic entrepreneurship: Convergencies, controversies, and conceptual advancements. International Migration Review, 38(3), 1040-107. 